\title{
AN EMPIRICAL EVALUATION OF THE POTENTIAL OF PUBLIC E-PROCUREMENT TO REDUCE CORRUPTION
}

\author{
Arjun Neupane \\ University of Southern Queensland \\ Email: Arjun.Neupane@usq.edu.au \\ Jeffrey Soar \\ University of Southern Queensland \\ Email: Jeffrey.Soar@usq.edu.au \\ Kishor Vaidya \\ University of Southern Queensland \\ and \\ University of Canberra \\ Email: Kishor.Vaidya@usq.edu.au \\ Kishor.Vaidya@canberra.edu.au
}

\begin{abstract}
One of the significant potential benefits of e-procurement technology is reducing opportunities for corruption in public procurement processes. The authors identified anticorruption capabilities of e-procurement through an extensive literature review and a theoretical model representing the impact of three latent variables: monopoly of power, information asymmetry, and transparency and accountability upon the dependent variable, the intent-to-adopt e-procurement. This research was guided by the PrincipalAgent theory and collected the perceptions of 46 government officers of the potential of public e-procurement to reduce corruption in public procurement processes. Results were analysed using the Partial Least Squares Structural Equation Modeling (PLS-SEM) approach. The findings suggest that the intent-to-adopt e-procurement has a positive and significant relationship with the independent variables that might inform developing countries in strategies to combat corruption in public procurement.
\end{abstract}

Keywords: Public procurement, public e-procurement, anti-corruption, monopoly power, information asymmetry, transparency, accountability

\section{INTRODUCTION}

There is interest amongst governments across the world in the adoption of Information and Communication Technology (ICT) tools for the promotion of the better service delivery (Ndou, 2004), greater transparency, and improved accountability (Bertot,Jaeger \& Grimes, 2010; Kim,Kim \& Lee, 2009). There is recognition that the implementation of public e-procurement technology is a key tool for reforming government public procurement processes. Thai (2001) pointed out that public procurement is a major function of government and Thai argued that government agencies, policy makers, and public procurement professionals have a great interest in public procurement reforms.

The potential benefits of e-procurement include reducing corruption risks (Iqbal \& Seo, 2008; Mistry \& Jalal, 2012). ICT-enabled technology tools that have been adopted by government include egovernment, e-governance, e-procurement, e-tendering, web-based ERP, e-services, e-democracy and other electronic services. Each system is developed for a purpose with its own specific function and 
characteristics. The main question is how these integrated systems link to reduce corruption. This study evaluates the perceived potential of perceived benefits of public e-procurement technologies to help to curb corruption. This study discusses three concepts: public procurement, corruption in public procurement, and how public e-procurement may help to reduce the risk of corruption.

Public procurement refers to the processes whereby public sector organizations acquire goods and services, works, and other activities from third parties. Governments spend much of their budget on goods and services. Government procurement of goods and services typically accounts for 10-15 \% of Gross Domestic Product (GDP) for developed countries (Kashap, 2004) and $20 \%$ to 70\% GDP in developing countries (GTN, 2003; UNDP, 2006). Vaidya, Callender and Sanjib, (2009, p 474) found that "governments aspire to use public procurement as a lever of economic, technological or social reform". Burton (2005) and Thai (2001) argued that public procurement is the central instrument and major function of the government to assist in the efficient management of public resources. Shakya (2012) research concluded that success factors of public procurement are value-for-money, transparency, non-discrimination, competition, and ethical behaviour.

The term corruption is defined as the exercise of public power for private gain (Cuervo-Cazurra \& Genc, 2008). Corruption can take different forms including bribery, theft, embezzlement, abuse of discretion, favouritism, exploiting conflict, putting private interests above public interests, and improper political contributions (UNODC, 2004). Corruption in public procurement is increasing especially in developing countries as evidenced by reports of the World Bank, the United Nations (UN), Transparency International, and the Asian Development Bank (ADB) reports. Corruption can hinder the development of country by weakening national institutions, increasing business costs, eroding trust, and discouraging external investment (Lio, Liu and Ou (2011). Raymond (2008) argued that corruption is a serious problem for developing countries that actively hinders their progress. The annual value of bribes paid worldwide is estimated at US \$1 trillion (WB, 2004). Corruption threatens the economic and human development of many countries. Corruption in public procurement processes is linked with unjustified and hidden procurement planning, lack of monitoring and controlling mechanism, lack of transparency and accountability, and weak professionalization of the bureaucracy of the countries (Del Monte \& Papagni, 2007; Kolstad \& Wiig, 2009; Neupane, Soar, et al., 2012; Pellegrini \& Gerlagh, 2008; Subedi, 2006; Ware et al., 2012).

Electronic procurement is the use of Information and Communication Technology (ICT) such as the Internet or web-based systems designed to facilitate the acquisition of goods and services by the government or by private institutions (Davila,Gupta \& Palmer, 2003). It has played a significant role in the successful management of public resources (Mahmood, 2010) and most importantly to better enhance the transparency and accountability of government procurement (Croom \& Brandon-Jones, 2005; Panda,Sahu \& Gupta, 2010; Vaidya,Sajeev \& Callender, 2006). For the purpose of this study public e-procurement has been defined as "the use of any internet based inter-organizational information systems which automates and integrate any parts of procurement process in order to improve efficiency, transparency, and accountability in the wider public sector" (Vaidya, 2007). The Internet is typically used for providing comprehensive information about bidding at a single web portal that can be accessed by the government and all the register potential bidders. Reducing corruption in government procurement is a key component of the agenda of governments around the world (Henriksen \& Andersen, 2003). Countries of Asia and the Pacific have increasingly adopted ICT systems in order to enhance government services and business transaction (Wescott, 2001).

Public e-procurement can be an important tool to help reduce the risk of corruption within public procurement systems. Asian Development Bank /OECD (2008, p. 129) stated that "public eprocurement plays an important role for minimising corruption in public procurement". E-procurement also has other numerous potential benefits including standardising and monitoring procurement, 
increasing transparency, reducing personal discretion in purchasing decisions, enhancing fair competition amongst bidders, avoiding human interference, and maximising value for money.

This study explored the perceived potential of public e-procurement to reduce corruption in the public sector by addressing the following research questions:

Which anti-corruption factors are associated with the intent to adopt public e-procurement technology? In particular:

- Are lower levels of perceived monopoly of power related to the willingness to adopt eprocurement as a form of anti-corruption technology?

- Are lower levels of perceived information asymmetry related to the willingness to adopt eprocurement as a form of anti-corruption technology?

- Are higher levels of perceived transparency and accountability related to the user's willingness to adopt e-procurement as a form of anti-corruption technology?

The paper is organised into eight sections. In Section Two, there is a discussion of the literature on anticorruption capabilities of public e-procurement. In section Three, there is a discussion of the theoretical foundation of the study. The development of the research hypothesis and research model based on Principal-Agent theory presented in Section Four. The research methodology has been discussed in Section Five. Section Six presents the empirical data analysis. Section Seven discusses the finding of the research and recommendation. In the final section, the Conclusion is presented, including academic contributions to literature and practitioner implications of the research.

\section{LITERATURE REVIEW}

It is clear that the recent boom of ICTs brought an extensive role for making transparent and accountable government as well as improving the living standards of global citizens. On the other hand, ICT can been seen as the leader for socio-economic development of many countries (Braund et al., 2007) and it is a crucial for sustainable development in developing countries (Credé,Mansell \& Mansell, 1998). Many scholars have identified that ICTs have the potential to reform the government work and services and to improve public sector service delivery (Singh et al., 2010), to support good governance (Basu, 2004), to promote transparency and anti-corruption (Bertot et al., 2010), to develop social capital (Shim \& Eom, 2009) and many more other benefits. Pathak et al. (2009) research highlighted based on the community perceptions on the service delivery that IT enabled technology such as electronic government initiatives can cut the corruption as well as reshape public sector activities and processes, increases overall transparency, and strength relations between government and citizens. Kim et al (2009) reported on an anti-corruption system called OPEN (Online Procedures Enhancement for civil application) which made a positive role in reduction of corruption. Citizens could access acquire real time information system on their applications, their status, estimated date of approval, and the reasons for decisions from OPEN system. Likewise, Krishnan, Teo and Lim (2013) study reveals that the maturity of e-government is seen to be linked to the effectiveness in reducing the level of corruption. Oye (2013) pointed out e-government has been seen to reduce the administrative corruption and transparency in service delivery in African developing countries.

In developing countries, major fraud and corruption happens in public procurement processes including procurement planning, project documentation, tender processes, contract awards and implementation, and accounting and auditing. Report published by Independent Commission Against Corruption (ICAC) Australia, clearly indicated that procurement processes are vulnerable to corruption (ICAC, 2011) and there is a risk of corruption in every stage of tendering process such as identification of needs and design of tenders, selecting a business, the bidding procedure, contract awards, and contract 
execution (OECD, 2007). Table 1 provides a link of public e-procurement anti-corruption factors to research papers.

\begin{tabular}{|c|c|}
\hline Anti-corruption factors & Some key references \\
\hline Avoid unnecessary purchase / project & (Achterstraat, 2011) \\
\hline $\begin{array}{l}\text { Real time access information or real time } \\
\text { bidding }\end{array}$ & (Ndou, 2004) \\
\hline Automation of procurement process & (Henriksen \& Mahnke, 2005) \\
\hline $\begin{array}{l}\text { Increase competition among the bidders or } \\
\text { suppliers }\end{array}$ & $\begin{array}{l}\text { (Hanna, 2010; IMF, 2010; Mahmood, 2010; Thai } \\
\text { 2001) }\end{array}$ \\
\hline Reduce human intervention in bidding process & (Khanapuri et al., 2011; Magrini, 2006) \\
\hline $\begin{array}{l}\text { Standardization enactment (More consistency in } \\
\text { procurement phase) }\end{array}$ & (UN, 2006; Zhang \& Yang, 2011) \\
\hline Monitoring and tracking application & (Achterstraat, 2011; ADB, 2010; OECD, 2011) \\
\hline Efficient and secure document transmission & $\begin{array}{l}\text { (AG, 2005; Chang, 2011; Hanna, 2010; Zhang \& } \\
\text { Yang, 2011) }\end{array}$ \\
\hline Managerial control and collaboration & (Henriksen \& Mahnke, 2005) \\
\hline Transparency and accountability & $\begin{array}{l}\text { (Croom \& Brandon-Jones, 2005; Panda et al., } \\
\text { 2010; Pathak et al., 2009; Vaidya et al., 2006) }\end{array}$ \\
\hline Make a procurement process faster and easier & (Hanna, 2010) \\
\hline Obtain the best quality / price ratio & $\begin{array}{l}\text { (Kaliannan,Raman \& Dorasamy, 2009; Lee,Oh } \\
\text { \& Kwon, 2008) }\end{array}$ \\
\hline
\end{tabular}

Table 1: Public e-procurement anti-corruption factors Source: (Neupane, Soar, et al., 2012)

There is limited research on ways to reduce corruption within public procurement. Vaidya et.al (2004) discussed twelve case studies and identified key benefits of public e-procurement in the Australian public sector based on the use of the Balanced Scorecard approach and critical success factors. Other literature discussed the key benefits of e-procurement including perceived direct benefits (Brun et al., 2010; Chang, Wang \& Chiu, 2008; Croom \& Brandon-Jones, 2007; Gunasekaran \& Ngai, 2008; Ho et al., 2008; Vaidyanathan \& Devaraj, 2008) that help to identify different key factors of better performance of public or private organizations including perceived direct benefits of e-procurement (Brandon-Jones \& Carey, 2011; Mitchell, 2000; Panayiotou, Gayialis \& Tatsiopoulos, 2004), perceived indirect benefits of e-procurement (Gunasekaran et al., 2009), perceived cost, firm size, top management support, information sharing culture, business partner influences (Teo, Lin \& Lai, 2009). Eei, Husain \& Mustaffa (2012) identified e-procurement's potential tangible and intangible benefits including enhanced efficiency and effectiveness in an organisation through reductions in costs and procurement process cycle times, increased transparency in contracts and overall competitiveness

E-procurement has been recognised as a core application in e-commerce / e-government (Ronchi et al., 2010). Research on combating corruption or anti-corruption includes: E-government as an anticorruption tool (Andersen, 2008), e-government for improved public sector service delivery in India, Ethiopia and Fiji (Singh et al., 2010), applying E-government Information System for Anti-corruption strategy (Zhang \& Zhang, 2009), e-government, Transparency and Anti-corruption (Fan,Zhang \& Yue, 
2009), anticorruption effects of information communication and technology and social capital (Shim \& Eom, 2009), using ICT to combat corruption- tools, methods and results (Grönlund et al., 2010), and an institutional analysis of an e-government system for anti-corruption: the case of Online Procedures Enhancement for civil application (OPEN) (Kim et al., 2009). Kin et al. (2009) study results indicate that the OPEN system made a positive impact in terms of a reduction of corruption within the Seoul Metropolitan Government. Studies regarding public procurement and corruption (Auriol, 2006; Lindskog,Brege \& Brehmer, 2010; Mahmood, 2010) indicate that the quality of public administration must be improved and made accountable. E-procurement can improve the transparency and integrity of public service processes such as tendering, sourcing, ordering, and auctioning. E-procurement has been recognised internationally as an important instrument for checking corruption and misuse of power (Sohail \& Cavill, 2008). E-procurement systems implemented in Korea and Mexico demonstrate how the innovative use of information technology to prevent and control corruption in public procurement (OECD, 2005).

The Nepalese e-government master plan was developed in 2006 with the main objective of a more efficient, productive, transparent, and responsible government that provides value-added quality service through ICT. The Nepalese government has progressively developed and implement IT-related policy, strategy, and legal framework including Information Technology Policy 2000, Telecommunication Policy 2004 and Electronic Transaction Act 2007 (Pariyar, 2007). The Nepalese Government's Public Procurement Act 2007 is one of the prime pieces of legislation designed to reform government procurement systems to make them more transparent, allowing for accountable government, fair, competitive, and efficient public procurement processes by ensuring equality of opportunity for the bidders to participate in public procurement processes without any discrimination (Nepal Public Procurement Strategic Framework, 2010).

Corruption in public procurement has been widespread around the world and is more serious and at a more alarming stage in developing countries (Iqbal \& Seo, 2008; Kumar et al.,2007). Poverty and low civil service salaries can motivate public officials to earn extra income via corruption (Bannon,1999). Other important factors that have driven corruption in public procurement include political instability, lack of transparency and accountability, monitoring and auditing of government works and services, low level of professionalism of the bureaucracy, and a weak separation between the civil society and politics (Del Monte \& Papagni, 2007; Kolstad \& Wiig, 2009; Subedi, 2006). Corruption in public procurement is a serious problem in Nepal, and due to the use of traditional paper-based purchasing systems, there is a potential to avoid the rule of law for securing contracts (Bhattarai, 2011). There are instances in Nepal where contracts and tenders are awarded because of an abuse of power and political interference. , government officers are also involved indirectly and use their official power for their own private benefit. Members of political parties are also involved and have manipulated public procurement process for their own ends. In the "Sudan Darfur Scam" the Special Court (SC) convicted three former police chiefs and two suppliers of embezzlement involving the purchase of an Armoured Personnel Carrier (APC) for the Nepalese peacekeeping mission in the Darfur region of Sudan (Sharma, 2012). ICT tools have the potential to assist countries like Nepal to combat the problem presented by systemic corruption.

\section{THEORETICAL APPROACH}

Theories provide guidelines that govern research and provide a structure to the concepts and relationships between constructs that collectively present logical, systematic, and coherent explanation of phenomenon of the interest with some assumption (Bacharach, 1989). This study has used agency theory that is also known as Principal-Agent model that refers to the relationship between two parties: the Principal and the Agent who makes the decision or takes any action on the behalf of the principal 
(Eisenhardt, 1989; Jensen \& Meckling, 1976). The Agency theory is considered one of the most important contributions in the fields of organisational economics, business management, and information systems research (Basu \& Lederer, 2011; Gefen \& Carmel, 2008; Oh,Gallivan \& Kim, 2006). Dawson, Watson and Boudreau (2011, p 1) suggest that "agency theory has long been a stalwart of IS research and is one of the most commonly used lenses to study the relationship between a principal and an agent". Agency theory can be useful in the contractual and social relationship between consultant and clients. It refers to the relationship between two parties: a principal and the agent where the one party (principal) delegates work to the other party (agent) and the agent takes any action on the behalf of the principal (Eisenhardt, 1989; Jensen \& Meckling, 1976). Originally, this concept was developed to assist the risk sharing between individuals and groups (Jensen \& Meckling, 1976). This theory was applied in different agency relationships including buyers and sellers (Waterman \& Meier, 1998), government and citizens (Singh et al., 2010), public institutions and bureaucracy (Lambsdorff, 2001).

In this study the government is the Principal body that provides public services to the people and Agents are the bidders (Contractor, supplier) who work for the government and are providers of goods and services. The main role of Principal or government authority is its responsibility for formulating policy options to help in the regulation and development of the public procurement, the monitoring of the various procurement activities, the regulation and maintenance of standards of procurement, capacitybuilding and professional development, information management and dissemination. Agents' roles are to bid for the government work and services, comply with all statutory, legal and award requirements relative to the work and services, complete all task within agreed cost structures, maintain quality and also complete all tasks within the designated time frame. In this regard, the main contribution of Principal-Agent Theory is to explain the risk of corruption in public procurement processes between two parties - Principal and Agent - and examine contracting problems to determine the most efficient contract type that will satisfactorily govern the Agency relationship (Whipple \& Roh, 2010). Principalagent theory helps explain how the major issue in managing agency relationships resides in ensuring that the agent acts in the interests of the principal.

The theory helps understand the risk of corruption in government procurement through considering: reduction of monopoly power, information asymmetry, and transparency and accountability within the public procurement processes as they affect the relationship between government officials and bidders (Neupane, Soar \& Vaidya, 2014). All of these factors are expected to have a relationship (either positive or negative) with a dependent variable, which is the intent-to-adopt e-procurement.

\section{DEVELOPMENT OF HYPOTHESIS AND RESEARCH MODEL}

In the context of the public procurement process, a government official plays an important role in the provision of goods and services and is the key person to provide a goods and services to the public in a transparent way. They may assign a public contract or tenders to favoured contractors or bidders. In some situations, "government officers have monopoly power over the provision of goods and services that are crucial for explaining the incidence of corruption without theft"(Neupane, Soar \& Vaidya, 2012b). Klitgaard (1988) pointed out that "Corruption tends to emerge when an organization or a public official has monopoly power over a good or service that generates rent, has the discretionary power to decide who will receive it, and is not accountable". This is more common in developing countries in relation to the awarding of public contracts where many tenders are assigned to favoured contractors or bidders for corrupt reasons. To avoid this issue, public e-procurement can be a great tool to reduce the monopoly on power held by government officials. E-procurement can help to reduce the risk of corruption by providing benefits such as real time information, fixed price contracts, automation and auditing controls, efficiency, and reduced accounting errors. All bidders can view tender documents 
through a public portal that provides greater transparency. They may be able to access real project information such project cost, and time. The following hypothesis summarises this relationship.

H1: Higher level of perception of the potential of public e-procurement to reduce monopoly power is positively related to the willingness to adopt.

Information asymmetry (IA) is a core component of the Principal-Agent Theory (Amagoh, 2009, p 6) and reducing information asymmetry problems is another key factor of public electronic government (Song, 2002). The relationship of Principal to Agent exists during the procurement processes between government tender administrators and bidders (Finkle, 2005; Larbi, 2006). Information asymmetry arises when the Agent has more information than the Principal, or vice versa, in the contract between government and bidders (Amagoh, 2009). These kinds of information gaps take place due to incomplete information, incompleteness of contract, problems with monitoring mechanisms, and the cost of configuration of the projects in contracting process (Finkle ,2005; Gauld, 2007; Taylor, 2005). In this regard, the perceived benefits of public e-procurement (see Appendix A) can be considered to reduce information asymmetry problems as well as to reduce the chances of corruption in public procurement. The present study examines this relationship:

H2: Higher level of perception of the potential of public e-procurement technology to reduce information asymmetry is positively related to the willingness to adopt.

Public e-procurement has a range of potential benefits for both process and transparency in public procurement, Schapper (2008, p 115) stated that "Procurement of goods, works, and services through Internet-based information technologies (e-procurement) is emerging worldwide with the potential to reform processes, improve market access, and promote integrity in public procurement". Transparency and openness are core principles of public procurement and transparency is widely recognised as a foundation of good governance (Parigi et al., 2004). Lack of transparency creates opportunities for the public officials such as government officers and politicians to abuse their positions of authority for private gain. This indicates a weak accountability mechanism that tends to facilitate corruption. Corruption flourishes due to a lack of transparency and accountability in public goods and services. As a result, corrupt bureaucrats realise that they can take advantage of regulation, so they generate layers of government regulation governing which in turn then runs the risk of making processes over-complex and vague and avoid detection. Accountability refers to the "service guarantee" of a govern $\neg$ ment; the extent to which its actions are accounted for and corrected if not carried out correctly in the first instance. Technically, accountability can be improved fairly and easily. Information can be published online, processes and decisions can be traced for audit and analysis, and there can be rules for compensation where accountability is not delivered. The following hypothesis summarises this relationship. 
H3: Higher level of perception of the potential of public e-procurement technology to increase transparency and accountability is positively related to the willingness to adopt.

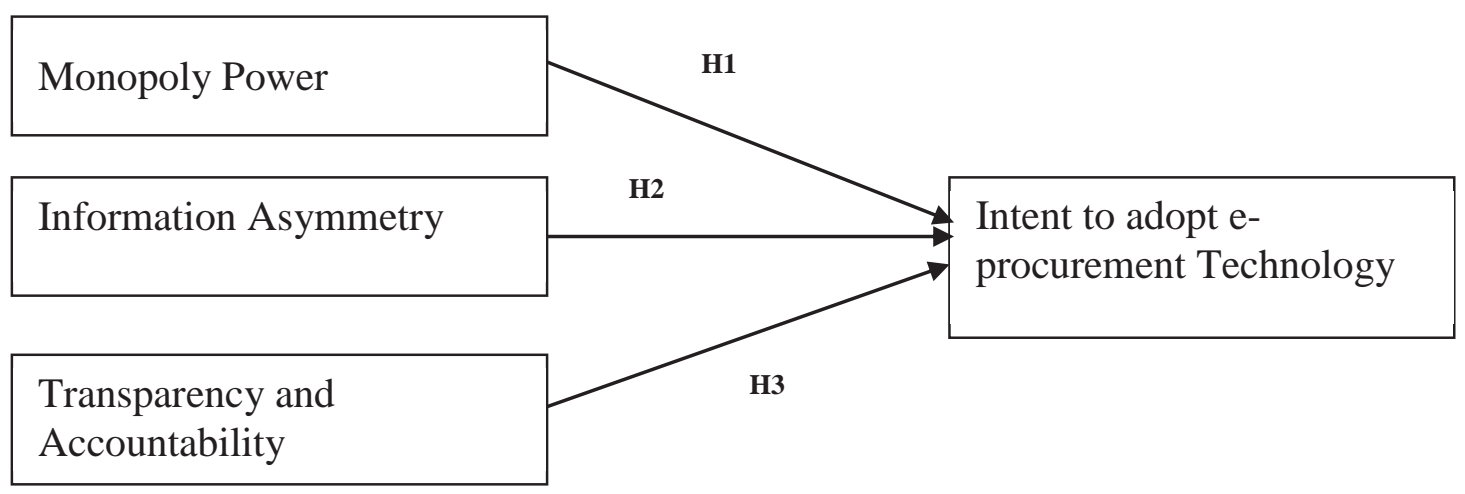

Figure 1: Research model of this study

The focus of this research is on the management of transparency and accountability for which eprocurement technology can be an enabler. Figure 1 presents the conceptual model of this study consisting of the hypothesis defined above. This model shows three independent variables as they relate to intent-to-adopt e-procurement technology as the dependent variable. Each dependent variable has different items that are shown in the Appendix. The most important perceived anti-corruption factors of public e-procurement technology include: real time access to information, automation of procurement processes, tracking and monitoring, consistency in procurement, competition among bidders, transparency, efficiency, quality, and accountability in public procurement. Similar kinds of research models were presented by Neupane et al. (2012a, p 6) as part of an evaluation of the anticorruption capabilities of public e-procurement in developing country. Yusoff \& Islam's (2011) study into electronic government procurement adoption behaviour amongst Malaysian SMEs supported this finding. Van der Heijden,Verhagen and Creemers (2003, p 44) presented a research model that furthers our understanding of online purchase intentions: contributions from technology and trust perspective. In the context of developing countries, the implementation of public e-procurement at the government level is in its infancy and its success and future prospects are not yet assured. Some developed countries such as Singapore, Denmark, Japan, New Zealand, and Australia have experienced success with public procurement resulting in greater levels of transparency. Other examples include the Republic of Korea and Andhra Pradesh (India) that have generated significant benefits to the government through eprocurement (Bhatnagar \& Singh, 2010; Chang, 2011).

\section{RESEARCH METHODOLOGY}

This study employed the positivist paradigm to examine the intent-to-adopt public e-procurement technology in government, and to explore perceptions of the potential of public e-procurement technology to reduce corruption in government procurement. In research context, positivist philosophy involves the hypothesis testing to obtain the objective truth and predict what may happen at the future date as well (Greener, 2008). The positivist philosophy has number of implication for social science research including methodological, value-freedom, causality, operationalization, independence, and reductionism (Bond, 1993; Easterby-Smith,Thorpe \& Lowe, 1997; Hughes, 1994).

The population for this study was drawn from the government departments of Nepal and was conducted in the capital city of Kathmandu. Most of the government departments' head offices are located in this region. The participants were invited from seven Nepalese government departments including the Department of Roads (DOR), Nepal Electric Authority, Department of Urban Development and 
Building Construction, Department of Local Infrastructure Development of Agricultural Roads, Roads Board of Nepal, Public Procurement Monitoring Office, and Ministry of Irrigation, Department of Water Induced Disaster Prevention. The main reason for selecting these organisations for this study was that they have already implemented, and are currently using public e-procurement systems. The participants' contact details were gathered from the Government of Nepal directory of government officials (http://nepalgov.gov.np). The researcher then took steps to confirm that the participants were indeed implementing and using public e-procurement systems.

The Public Procurement Monitoring Office (PPMO) is a guiding body for procurement policy formulation, implementation, and monitoring procurement system in Nepal. The main mission of PPMO is to maintain transparency, accountability, effectiveness, efficiency, and as well as nondiscrimination and equality in public procurement processes in Nepal. The PPMO installed (http://gepson.gov.np) as a single web portal system for all public entities of government procurement of Nepal. The PPMO has begun the process of creating a centralised web portal. Some of the government departments are also using the DOR web portal (http://eproc.dor.gov.np/) for procurement. DOR was the first organisation to introduce public e-procurement for submission and opening of bids in Nepal in 2008.

Research participants included government officers who were involved in procurement and administration sections including Joint Secretary, Director, Senior Divisional Engineer, Computer Officer, IT Manager, and Training Officer. The study used a convenience sampling approach as determined by the level of interest shown by the participants to respond to the survey and finally 46 Government Officers were approached to complete questionnaire survey. The items used in the field survey are listed in Appendix A. Survey research has several inherent strengths compared to other research methods because it measures a wide range of unobservable data such as peoples' attitudes, beliefs, factual information and behaviours (Bhattacherjee, 2012, p. 73). In this research, data was collected through face-to-face field surveys. Firstly, the researcher discussed and asked questions of the participant about public e-procurement. Secondly, a questionnaire was conducted to collect the data related to the measuring of the perceived benefits of public e-procurement in the context of reducing corruption. The study explored three independent variables: monopoly on power, information asymmetry, transparency and accountability. Each construct has different scale measurement item, and those items were measured by asking the respondents perceptions on e-procurement benefits and its application. All the variables are coded on a five-point Likert scale ranging from "Strongly Disagree" to "Strongly Agree".

\section{DATA ANALYSIS}

The collected data was analysed quantitatively using Partial Least Squares (PLS) SmartPLS 2.0. PLS path modelling (PLS-PM) or PLS Structural Equation Modeling (PLS-SEM) is a method for data analysis and has been used in various fields of computer science, marketing, accounting, management and psychology (Ismail,Hamid \& Idris, 2012). PLS-PM has been considered as a very flexible and soft modelling approach to multi block analysis by the means of both hierarchical PLS path model and more as exploratory approach than a confirmatory one (Vinzi,Trinchera \& Amato, 2010). Hanafi (2007) pointed out PLS-PM is a statically different approach from covariance structure analysis for path analysis with latent variables, interpretation of the basic entities of model, type, and parameters. PLS can be used when the sample size is relatively small (Chin, 1998a; Henseler,Ringle \& Sinkovics, 2009; Lehner \& Haas, 2010; Wetzels, Odekerken-Schroder \& Van Oppen, 2009). Likewise, PLS is used to predict complex relationships in a large model with multiple independent variables and multiple dependent variables (Abdi, 2003). PLS aids the prediction of dependent endogenous variables through 
latent variable scores that can be used to predict models (Chin 1998a; Henseler et al., 2009), and supports continuous moderation without losing information (Chin, 1998a).

The reliability of cross loading value of the measurement items is illustrated in Appendix B. loading should exceed over 0.70 to be considered (Carmines \& Zeller, 1979). Other authors suggest that the cross loading value above 0.40 or 0.50 is appropriate (Hulland, 1999). In this study, based on the PLSPM results (Appendix B), all the items had a range from 0.481 to 0.924. Lew and Sinkovics (2012, p 23) suggested that a score of outer loading over 0.5 can be acceptable and Chin (1998a) stated 0.40 can be acceptable. As a result, the factor loading met the recommended threshold value 0.4 (Chin, 1998a; Henseler et al., 2009).

Table 2 presents the results of reliability of the construct, including Average Variance Extracted (AVE), composite reliability, and Cronbach's alpha. All the constructs demonstrate the composite reliability (CR) and Cronbach's alpha value is higher than 0.70 that is greater than the threshold value 0.7. George $\&$ Mallery (2003, p. 231) provided the range of Cronbach's Alpha values as " $>$.9-Excellent, >.8-Good, >.7-Acceptable, >.6-Questionnable, >.5-Poor". The CR values of construct ranged from 0.81 to 0.90 , all greater than the threshold value of 0.7 (Bagozzi \& Yi 1988). Henseler et al. (2009) suggested that the AVE value of above 0.50 indicates the sufficient level of convergent validity. Our results also reveal AVE value is greater than 5.0 except information asymmetry that is also close to 0.5 .

\begin{tabular}{|l|l|l|l|}
\hline Variables & AVE & $\begin{array}{l}\text { Composite } \\
\text { Reliability }\end{array}$ & Cronbach's Alpha \\
\hline Information Asymmetry (IA) & 0.477 & 0.810 & 0.713 \\
\hline Monopoly of Power (MP) & 0.557 & 0.880 & 0.833 \\
\hline $\begin{array}{l}\text { Transparency and Accountability } \\
\text { (TA) }\end{array}$ & 0.624 & 0.890 & 0.849 \\
\hline Intent to adopt e-procurement (ITA) & 0.544 & 0.903 & 0.881 \\
\hline
\end{tabular}

Table 2: Reliability and validity of constructs

Discriminant validity is another type of construct validity used in PLS path modelling and table 3 demonstrates the square root of AVE for each construct were greater than the highest correlation between that the construct and the other constructs (Fornell \& Larcker, 1981; Gefen \& Straub, 2005). The diagonal elements highlighted in bold (square root of AVE), are greater than the off-diagonal elements.

\begin{tabular}{|l|l|l|l|l|}
\hline Variables & IA & MP & TA & ITA \\
\hline IA & 1.000 & & & \\
\hline MP & 0.864 & 1.000 & & \\
\hline TA & 0.790 & 0.794 & 1.000 & \\
\hline ITA & 0.633 & 0.669 & 0.448 & 1.000 \\
\hline
\end{tabular}

Table 3: Latent construct correlation table with squared of AVE values

The exploratory power of the PLS structural model can be evaluated by examining the amount of variation in the dependent variables that can be explained by the model Figure 2. information asymmetry was found to be a most important driver for intent-to-adopt public e-procurement, with a 
path coefficient equal to 0.459 . Other important factors included monopoly power and transparency and accountability path with coefficient values of $0.328,0.231$ respectively.

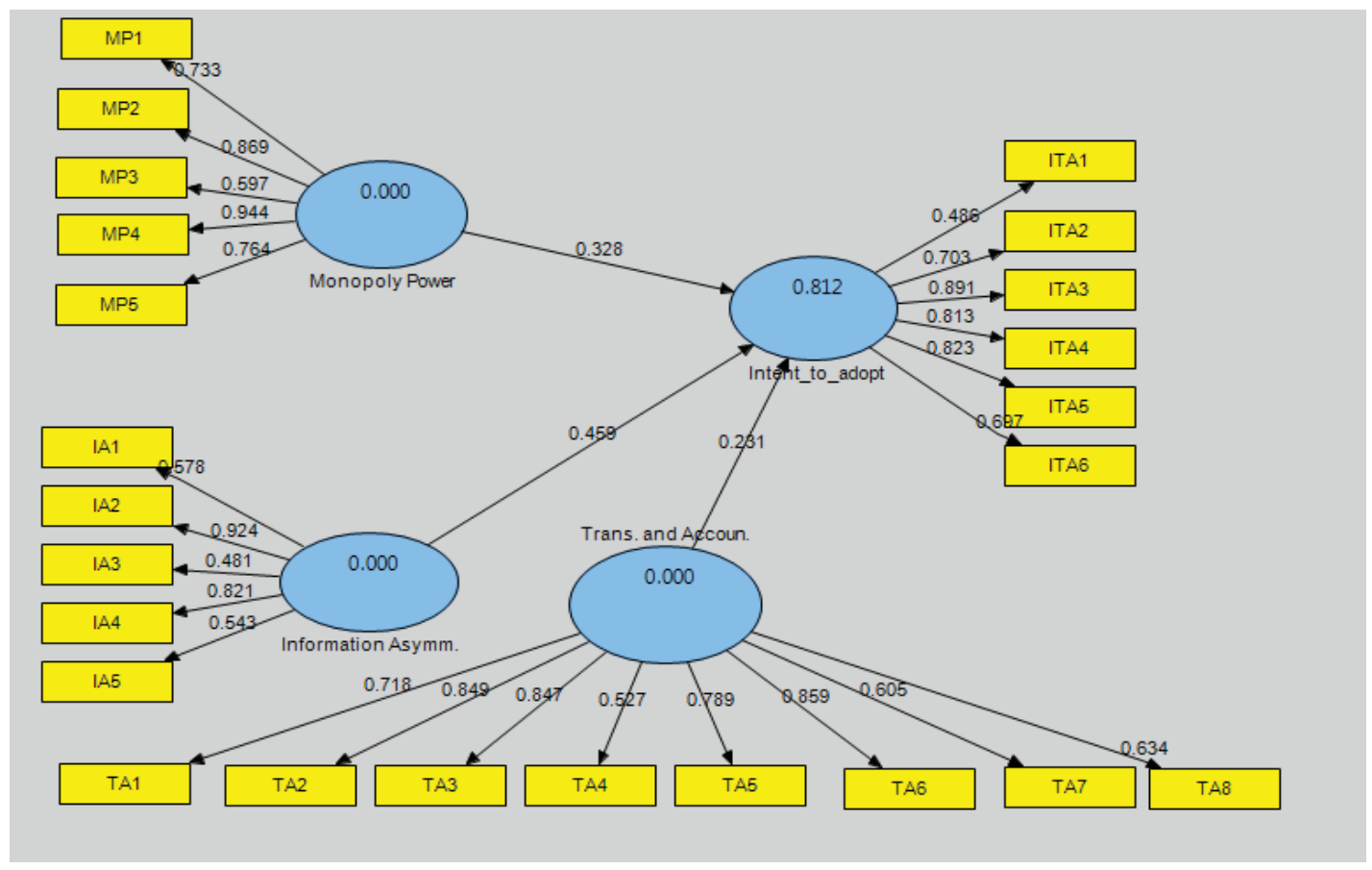

Figure 2: PLS Structural Equation model

The R2 value (Figure 2) is 0.812 that is interpreted as 81.20 percent of the variation in the level of intent-to-adopt e-procurement significantly explained by the PLS model. PLS-PM is a component based estimation method (Chin, 1998a; Vinzi et al., 2010) and it uses an iterative algorithm to obtain latent variables estimates through the system of multiple regression or simple linear regression (Aibinu \& AlLawati, 2010). This study uses Partial Least Square (PLS) regression for obtaining cross loading, path coefficient, discriminant validity, R2 value, and weight value for the latent variables of the measurement items. The below equation presents the PLS regression model of the equation: Intent-toadopt e-procurement $($ ITA $)=0.328 * \mathrm{MP}+0.459 * \mathrm{IA}+0.231 * \mathrm{TA}$.

In PLS-PM structural equation modelling, the bootstrapping method was used to test the significant of paths in the study measurement model. The bootstrap is an alternative way to produce better approximations for the true small sample properties (Schmidheiny \& Basel, 2012). Bootstrap techniques are used for testing hypothesis (Beaumont \& Bocci, 2009) and Chin (1998a)undertook bootstrapping with 500 samples. Hair, Ringle \& Sarstedt (2011) considered that critical t-values for two-tailed test need to be 1.65 (significance level =10 percent), 1.96 (significance level $=5$ percent), and 2.58 (significance level=1 percent). Table 5 demonstrated the standardised path coefficient results and hypothesis test. The result found that all the independent variables are positively significant to the dependent variables intent-to-adopt e-procurement $(\mathrm{MP} \beta=0.328 \mathrm{t}$-value $=2.767 \mathrm{p} \mathrm{0.01;} \mathrm{IA} \beta=0.459 \mathrm{t}$ value $=3.374$ p 0.01; TA $\beta=0.231 \mathrm{t}$-value $=2.492$ p 0.05 ).

Table 4 shows the standardised path coefficient results and hypothesis test. All the independents variables were found to be positive and significantly strong correlated with the dependent variables intent-to-adopt public e-procurement. The Path Coefficient value needs to be least 0.20 and ideally above 0.30 in order to considered as a strong relationship and meaningful for discussion (Chin, 1998b). 


\begin{tabular}{|l|l|l|l|l|}
\hline Hypothesis & $\begin{array}{l}\text { Path coefficient } \\
\text { value }\end{array}$ & t-value & $\begin{array}{l}\text { Sig. (two- } \\
\text { tailed }\end{array}$ & Supported? \\
\hline $\begin{array}{l}\text { H1: Monopoly Power--->Intent to } \\
\text { adopt }\end{array}$ & 0.328 & 2.767 & Sig. at 1\% & Yes \\
\hline $\begin{array}{l}\text { H2: Information Asymmetry--->Intent } \\
\text { to adopt }\end{array}$ & 0.459 & 3.374 & Sig. at 1\% & Yes \\
\hline $\begin{array}{l}\text { H3: Transparency and accountability-- } \\
->\text { Intent to adopt }\end{array}$ & 0.231 & 2.492 & Sig. at 5\% & Yes \\
\hline
\end{tabular}

Table 4: Path Coefficient (Intent to adopt e-procurement)

This relationship suggests that higher levels of adopting public e-procurement technology in government levels lowers the risk of the exercise of monopoly power by government officers in government procurement, minimising the information gap between government and its bidders in contracting process, and increasing higher level of transparency and accountability in public procurement. These outcomes ultimately will help to reduce the chances of corruption.

\section{DISCUSSION}

This study set out to research the perceptions of government officers on the potential of e-procurement for reducing corruption. The study contributes to the existing literature on the perceived benefits of public e-procurement by combining the different constructs into a single research model and by direct link to intent-to-adopt e-procurement.

The principal-agent theory applied in this research helps to evaluate the technology benefits including transparent and real time information, automation of transaction process, fixed price contract, track, and monitor, fairness of competition, and in reducing the chances of corruption in public procurement.

The results suggest that monopoly power, information asymmetry, and transparency and accountability are antecedent attitudes towards intent-to-adopt public e-procurement. All the latent variables were positively significant to the intent-to-adopt public e-procurement. our results indicate that a positive and strong relationship $(\beta=0.328)$ between reduction of monopoly power and intent to adopt public eprocurement which is similar to the research electronic government production behaviour observed amongst Malaysian SMEs conducted by Yusoff \& Islam (2011). Monopoly power of officials is one of the critical factors bearing upon opportunities for corruption (Klitgaard, 1988). Public e-procurement can reduce the power of government officers in procurement processes.

Information asymmetry and intent to adopt e-procurement were found to be correlated with each other $(\beta=0.459)$. Information asymmetry is a critical factor in principal-agent relationship that leads to create an information gap and a problem for monitoring between two parties. Singh \& Sirdeshmukh (2000) argued that asymmetrical information increases the probability of opportunistic behaviour. Wathne and Heide (2000) found that information asymmetry is a facilitating condition for opportunism. Xinzhang \& Yonggang (2011) suggested that public procurement application could enhance transparency, accountability, economic performance, and efficiency and mitigate the asymmetric information by increasing accessing information. This study believed found that public e-procurement is seen to reduce the information gap (lowering information asymmetry problem) between government and bidders. A lower level of information asymmetry directly decreases opportunities of corruption in public procurement. 
Our results indicate that transparency and accountability was positively significant $(\beta=0.231)$ to the intent to adopt e-procurement. Both transparency and accountability are two important pillars for the government and bidders to reduce corruption. Kolstad and Wiig (2009) claimed that transparency can reduce the political and bureaucratic corruption as well as facilitate cooperation over opportunistic rentseeking, maintain norms of integrity, and trust. , public e-procurement can facilitate real time access to information, automated procurement procedures, more consistency in bidding procedures, and importantly can reduce the human intervention in bidding processes. Our research found that these anticorruption factors lead to reducing the chances of corruption. Filho \& Mota (2012) and found that the main contribution of e-procurement to reforming government procurement system and enhanced efficiency and quality of government services, as well as enhance transparency and accountability (Brun et al., 2010; Wen \& Wei, 2007).

The finding also supports previous research by Neupane et al. (2012a) that highlighted the anticorruption capabilities of public e-procurement in developing countries. Pathak et al. (2008) suggests that electronic government initiatives improved government-citizen relationship and reduce corruption. Carayannis and Popescu (2005) found that information technology provides an opportunity to make procurement activities more transparent and accountable. Kim, Kim and Lee (2009) demonstrated that electronic government has made a positive impact upon improving transparency in the government sector as well as helping to combat corruption. Our findings are in line with recent research conducted by Vaidya \& Hyde (2011) who evaluated the benefits of public e-procurement in light of the diffusion of innovation theory.

The limitations of our research include that it was conducted in only one country and only with government officials. Future research will need to work on cross-sectional country analysis, adding more variables, and employing rigorous research methodologies interview, focus group discussion about the better understanding of perceived benefits of e-procurement to reduce corruption in public procurement. more research is need to identify the anti-corruption factors of perceived benefits of technologies in reducing corruption in government procurement and it also need to be strong empirical test to valid the factors that influence the adoption of e-procurement systems. The results of this study should be considered in the context of governments' public e-procurement and anti-corruption policies. This has been supported by Concha et al. (2012) who observe that e-procurement has profoundly transformed the Governments' procurement process exceeding the policy makers' expectations.

The result of this study has several interesting contributions for both procurement practitioners and government agency focus on performance of public e-procurement for reducing corruption in public procurement. Based on the above discussion, the study has suggested some practical recommendations:

\section{Government can encourage e-procurement as an anti-corruption reform in public procurement}

This study results suggest that the emerging countries' governments can promote public e-procurement as an anti-corruption tool to fight against corruption. Countries can encourage the awareness of transparency and accountability as key instruments tools for promoting integrity and preventing fraud and corruption in public procurement. Government can do the excellent job through the e-procurement web portal of creating transparent and accountable government works and services. It can help to provide publically available and open procurement related information in a web e.g. forms, contracts, bids, and awards. However, political will and efforts are necessary to implement the public eprocurement in the country. Governments should give priority for e-procurement in budgeting and ministerial decisions.

\section{Prioritise and promote public e-procurement as an anti-corruption agenda}

Governments should promote public e-procurement as an anti-corruption tool and promote awareness of transparency and accountability as key instruments for reducing fraud and corruption in public 
procurement. Governments should give priority for e-procurement in budgeting and ministerial decisions.

\section{Use public e-procurement initiative to drive administrative reforms}

A review and consolidation of the existing legislative framework is necessary for government administrative reforms so that it can give a clear transformation and wider support procurement issues. Governments need to develop policies to support adopting public e-procurement and launch awareness raising education and training, seminar to the companies including suppliers, contractor, and government agencies. Having recognised that procurement policies help governments to work, services to be more transparent, and reduce opportunities for corruption in public procurement.

\section{Incorporate the anti-corruption capabilities of public e-procurement in the technical/design phase}

Governments should identify the key measures of anti-corruption in public procurement and incorporate the anti-corruption capabilities in the technical design of pubic e-procurement. There is a need to develop an evaluation strategy to measure progress that defines what to measure and how to measure.

Develop and implementation of public e-procurement strategy in planning level:

Governments should make action plans for implementing public e-procurement and establish a steering committee of executives whose credentials are impeccable to develop a public e-procurement implementation strategy. The main mission of the strategy should be designed to centralise eprocurement system, which makes to increase monitoring capabilities, transparency and accountability, easy access to information, and make consistency to all bidders and government agencies. As a result, it helps to combat corruption.

\section{CONCLUSION}

This study has some either academic or theoretical and practitioner implications for government and international agency, and procurement practitioner of developing and transitioning countries to make decisions about e-procurement system. Academically, this paper has developed a research model based on the existing Principal-Agent Theory as well as public procurement research. This model can help to explain the relationship among the anti-corruption factors with intent-to-adopt public e-procurement. At a glance, the model provided reveals the opportunities to access the impacts of public e-procurement perceived benefits likely to reduce the chances of corruption in public procurement. From the point of view of the practitioner, it provides for better understanding of the potential of public e-procurement; as well as impetus to promote and prioritise public e-procurement as an anti-corruption agenda and the strength and relevance of use of technologies to procurement reform.

This paper identifies the three significant latent variables that could influence the willingness to adopt e-procurement at all levels of government on the perception of the government officers. It demonstrates the interesting feature of the potential of public e-procurement in reducing corruption in public procurement processes. It also reveals the higher level of intent-to-adopt public e-procurement has a positive relationship with the concept of reduction of monopoly power and information asymmetry, and transparency and accountability that contributes to the reduced chances of corruption in public procurement. The research objective was to identify the most important anti-corruption factors of public e-procurement on the perception of the government officers in relation to intent-to-adopt eprocurement. 


\section{REFERENCES}

Abdi, H. (2003) "Partial least squares regression (PLS-regression)", in M Lewis-Beck, Bryman,A., \& Futing, T. (ed.), Encyclopedia of Social Science Research Methods, Thousand Oaks, CA: Sage, 792-5.

Achterstraat, P. (2011) Compliance Review Report - Procurement Reform of e-Procurement and eTendering, The Legislative Council Parliament House, Sydney NSW 2000, http://www.audit.nsw.gov.au/ArticleDocuments/190/03_Vol_1_2011_Compliance_Review.pd f.aspx?Embed=Y accessed 5 January 2012

ADB (2010) (Asian Development Bank) Technical Assistance Report, Republic of Indonesia: Streangthing National Public Procurement Process, Manila.

AG (2005) (Australian Government) Case Studies on E-procurement Implementations Italy, New South Wales, New Zealand Scotland, Western Australia, Attorney-General's Department,Canberra, Australia, $\quad$ http://www.finance.gov.au/publications/e-procurement-researchreports/docs/Case_Studies_on_E-procurement_Implementations.pdf accessed 10 October 2011.

Aibinu, A.A. \& Al-Lawati, AM (2010) "Using PLS-SEM technique to model construction organizations' willingness to participate in e-bidding", Automation in Construction, 19(6), 71424.

Amagoh, F. (2009) "Information asymmetry and the contracting out process", The Innovation Journal: The Public Sector Innovation Journal, 14(2), 1-14.

Andersen, T.B. (2008) E'government as an anti'corruption tool, Department of Economics, University of Copenhagen, StudiestrÊde 6, DK-1455, Copenhagen K, Denmark.

Auriol, E. (2006) "Corruption in procurement and public purchase”, International Journal of Industrial Organization, 24(5), 867-85.

Bacharach, S.B. (1989) “Organizational theories: Some criteria for evaluation", Academy of Management Review, 14(4), 496-515.

Bagozzi, R.P. \& Yi, Y. (1988) "On the evaluation of structural equation models", Journal of the Academy of Marketing Science, 16(1), 74-94.

Bannon, L. (1999) The Fight Against Corruption : A World Bank Perspective, http://www.iadb.org/regions/re2/consultative_group/groups/transparency_workshop6.htm accessed 16 July 2013.

Basu, S. (2004) "E-government and developing countries: an overview”, International Review of Law, Computers \& Technology, 18(1), 109-32.

Basu, V. \& Lederer, A. (2011) "Agency theory and consultant management in enterprise resource planning systems implementation”, SIGMIS Database, 42(3), 10-33.

Beaumont, J-F. \& Bocci, C. (2009) "A practical bootstrap method for testing hypotheses from survey data”, Survey Methodology, 35(1) 25-35.

Bertot, J., Jaeger, P. \& Grimes, J. (2010) “Using ICTs to create a culture of transparency: E-government and social media as openness and anti-corruption tools for societies", Government Information Quarterly, 27(3) 264-71.

Bhatnagar, S.C. \& Singh, N. (2010) "Assessing the Impact of E-government: A Study of Projects in India”, Information Technologies \& International Development, 6(2) 109-27.

Bhattacherjee, A. (2012), Social Science Research: Principles, Methods, and Practices, 2nd edition edn, Open Access Textbooks, Book 3, http://scholarcommons.usf.edu/oa_textbooks/3/. 
Bhattarai, P., (2011) Curbing Procurement Corruption', Voices Against Corruption, http://voicesagainst-corruption.ning.com/profiles/blogs/curbing-procurement-corruption accessed 10 June 2013.

Bond, S. (1993) "Experimental research nursing: necessary but not sufficient”, in A Kitson (ed.), Nursing, Art and Science, Chapman and Hall, London.

Brandon-Jones, A. \& Carey, S. (2011) "The impact of user-perceived e-procurement quality on system and contract compliance", International Journal of Operations \& Production Management, 31(3) 274-96.

Braund, P., Frauscher, K., Schwittay, A. \& Petkoski, D. (2007) Information and Communications Technology for Economic Development Exploring Possibilities for Multi-sector Technology Collaborations, Global E-Discussion, The World Bank.

Brun, A., Ronchi, S., Fan, X. \& Golini, R. (2010) "What is the value of an IT e-procurement system?", Journal of Purchasing and Supply Management, 16 131-40.

Burton, R. (2005) "Improving Integrity in Public Procurement: The Role of Transparency and Accountability", in Fighting Corruption and Promoting Integrity in Public Procurement, OECD Publishing, 23-8.

Carayannis, E.G. \& Popescu, D. (2005) "Profiling a methodology for economic growth and convergence: learning from the EU e-procurement experience for central and eastern European countries", Technovation, 25(1) 1-14.

Carmines, E.G. \& Zeller, R.A. (1979) "Reliability and validity assessment", Sage University paper series on quantitative applications in the social sciences, 17, Sage Publications, Sage Beverly Hills, CA.

Chang, H.L., Wang, K. \& Chiu, I. (2008) "Business-IT fit in e-procurement systems: evidence from high-technology firms in China”, Information Systems Journal, 18(4) 381-404.

Chang, K-s. (2011) Enhancing Transparency through e-Procurement, Public Procurement Service (PPS) The Republic of Korea, http://www.oecd.org/dataoecd/47/30/49311011.pdf accessed 12 February 2012.

Chin, W.W. (1998a) "The partial least squares approach for structural equation modeling”, in GA Marcoulides (ed.), Modern Methods for Business Research Lawrence Erlbaum Associates Publishers, New Jersey, pp. 295-336.

Chin, W.W. (1998b) "Issues and opinion on structural equation modeling”, MISQ., 22(1) 7-16.

Concha, G., Astudillo, H., Porrúa, M. \& Pimenta, C. (2012) "E-Government procurement observatory, maturity model and early measurements", Government Information Quarterly, 29, S43-S50.

Credé, A., Mansell, R. \& Mansell, R.E. (1998) Knowledge societies--in a nutshell: information technology for sustainable development, IDRC, Ottawa, Canada.

Croom, S. \& Brandon-Jones, A. (2007) "Impact of e-procurement: Experiences from implementation in the UK public sector", Journal of Purchasing and Supply Management, 13(4) 294-303.

Croom, S.R. \& Brandon-Jones, A. (2005) "Key issues in e-procurement : Procurement implementation and operation in the public sector", Journal of Public Procurement, 5(3) 367-87.

Cuervo-Cazurra, A. \& Genc, M. (2008) "Transforming disadvantages into advantages: developingcountry MNEs in the least developed countries", Journal of International Business Studies, 39(6) 957-79.

Davila, A., Gupta, M. \& Palmer, R. (2003) "Moving Procurement Systems to the Internet::: the Adoption and Use of E-Procurement Technology Models", European Management Journal, 21(1) 11-23. 
Dawson, G, Watson, R. \& Boudreau, M-C. (2011) “An Empirical Test of the Theory of Relationship Constraints", paper presented to Thirty Second International Conference on Infromation Systems, Shanghai

Del Monte, A. \& Papagni, E. (2007) “The determinants of corruption in Italy: Regional panel data analysis", European Journal of Political Economy, 23(2) 379-96.

Easterby-Smith, M., Thorpe, R. \& Lowe, A. (1997) Management Research: an Introduction, Second edn, SAGE, London.

Eei, K.S., Husain, W. \& Mustaffa, N. (2012) "Survey on Benefits and Barriers of E-Procurement: Malaysian SMEs Perspective", International Journal on Advanced Science, Engineering and Information Technology, 2(6) 14-9.

Eisenhardt, K. (1989) “Agency theory: An assessment and review”, Academy of Management Review, 14(1) 57-74.

Fan, Y., Zhang, Z. \& Yue, Q. (2009) “E-Government, Transparency and Anti-corruption”, paper presented to 2009 International Conference on Management of e-Commerce and e-Government, 16-19 September, Nanchang, China.

Filho, J.R. \& Mota, F.P.B. (2012) "Public E-procurement Implementation: Insights from the Structuration Theory", in K Vaidya (ed.), Inter-Organizational Infromation Systems and Business Management : Theories for Researcher, IGI Global, Hershey, PA, USA, p. 259.

Finkle, A. (2005) "Relying on information acquired by a principal", International Journal of Industrial Organization, 23(3-4) 263-78.

Fornell, C. \& Larcker, D.F. (1981) "Evaluating structural equation models with unobservable variables and measurement error", Journal of Marketing Research, 18(1) 39-50.

Gauld, R. (2007) "Principal-agent theory and organizational change", Policy Studies, 28(1) 17-18.

Gefen, D. \& Straub, D. (2005) “A practical guide to factorial validity using PLS-Graph: Tutorial and annotated example", Communications of the Association for Information Systems, 16(1) 109.

Gefen, D. \& Carmel, E. (2008) "Is the world really flat? A look at offshoring in an online programming marketplace”, MISQ, 32(2) 367.

George, D. \& Mallery, P. (2003) SPSS for windows step by step: A simple guide and reference, 11.0 update, Boston, MA: Allyn \& Bacon.

Greener, S. (2008) Business research methods, Ventus Publising ApS, London, United Kingdom.

Grönlund, Å. (2010) "Using ICT to combat corruption-tools result and methods", Increasing transparency \& fighting corruption through ICT,Stockholm University,Stockholm Sweeden.

GTN (2003) Global Trade Negotitation,s Centre for International Development at Harvard University: Government Procurement", http://www.cid.harvard.edu/cidtrade/issues/govpro.html accessed 14 October 2011

Gunasekaran, A. \& Ngai, E.W.T. (2008) “Adoption of e-procurement in Hong Kong: An empirical research", International Journal of Production Economics, 113(1) 159-75.

Gunasekaran, A., McGaughey, R.E., Ngai, E.W.T. \& Rai, B.K. (2009) "E-Procurement adoption in the Southcoast SMEs", International Journal of Production Economics, 122(1) 161-75.

Hair, J.F., Ringle, C.M. \& Sarstedt, M. (2011) "PLS-SEM: Indeed a silver bullet", The Journal of Marketing Theory and Practice, 19(2) 139-52.

Hanafi, M. (2007) "PLS Path modelling: computation of latent variables with the estimation mode B", Computational Statistics, 22(2, ) 275-92.

Hanna, N.K. (2010) Transforming government and building the information society: challenges and opportunities for the developing world, Springer Verlag. 
Henriksen, H. \& Andersen, K. (2003) “e-Procurement Adoption: Theory and Practice”, in JH G. Goos, and J. van Leeuwen (ed.), Electronic Government, Springer Berlin 2739, 121-4.

Henriksen, H.Z. \& Mahnke, V. (2005) "E-procurement adoption in the Danish public sector", Scandinavian Journal of Information Systems, 17(2) 5-26.

Henseler, J., Ringle, C.M. \& Sinkovics, R.R. (2009) "The use of partial least squares path modeling in international marketing", Advances in International Marketing, 20(1) 277-319.

Ho, CF, Tai, Y.M., Wu, W.H. \& Jou, J.J. (2008) "Exploring the impacts of web-based e-procurement on organizational performance", PACIS 2008 Proceedings, p. 106.

Hughes, J. (1994) The Philosophy of Social Research, Essex, Logman.

Hulland, J. (1999) "Use of partial least squares (PLS) in strategic management research: a review of four recent studies", Strategic Management Journal, 20(2) 195-204.

ICAC (2011) Corruption risks in NSW government procurement: Suppliers Perceptions of corruption, Independent Commission Against Corruption, Sydney, NSW, Australia.

IMF (2010) Maldives: Public Financial Management-Performance Report, International Monetary Fund 10/137 Washington, D.C. USA.

Iqbal, M. \& Seo, J. (2008) "E-governance as an anti corruption tool: Korean cases", Korean Local Information, 11(2) 51-78.

Ismail, IRb, Hamid, RbA \& Idris, F. (2012) "PLS Application In Journal Of Operations Management: A Review", paper presented to Global Conference on Operations and Supply Management (GCOM 2012), Bandung, Indonesia, 12-13 March 2012.

Jensen, M.C. \& Meckling, W.H. (1976) "Theory of the firm: Managerial behavior, agency costs and ownership structure”, Journal Of Financial Economics, 3(4) 305-60.

Kaliannan, M., Raman, M. \& Dorasamy, M. (2009) "E-procurement adoption in the malaysian public sector: organizational perspectives", paper presented to Enterprise Distributed Object Computing Conference Workshops, Auckland, 1-4 September 2009.

Kashap, S. (2004) "Public Procurement as a Social, Economic and Political Policy", paper presented to International Public Procurement Proceedings, Florida USA, October 21-24, 2004.

Khanapuri, V.B., Nayak, S., Soni, P., Sharma, S. \& Soni, M. (2011) "Framework to Overcome Challenges of Implementation of E-procurement in Indian Context", paper presented to International Conference on Technology and Business Management, Dubai, March 28-30, 2011.

Kim, S., Kim, H.J. \& Lee, H. (2009) "An institutional analysis of an e-government system for anticorruption: The case of OPEN", Government Information Quarterly, 26(1) 42-50.

Klitgaard, R. (1988) Controlling Corruption, University of California Press, USA, Berkeley.

Kolstad, I. \& Wiig, A. (2009) "Is Transparency the Key to Reducing Corruption in Resource-Rich Countries?", World Development, 37(3) 521-32.

Krishnan, S., Teo, T.S. \& Lim, V.K. (2013) "Examining the relationships among e-government maturity, corruption, economic prosperity and environmental degradation: A cross-country analysis", Information \& Management, 50(8) 638-49.

Kumar, V., Mukerji, B., Butt, I. \& Persaud, A. (2007) "Factors for successful e-government adoption: a conceptual framework", The Electronic Journal Of E-Government, 5(1) 63-76.

Lambsdorff, J. (2001) How corruption in government affects public welfare: A review of theories, Zentrum für Globalisierung und Europäisierung der Wirtschaft, Georg-August-Univ.

Larbi, G. (2006) "New Public Management as a Template for Reforms in Low-Income Countries: Issues and Lessons from Ghana", International Journal of Organization Theory and Behavior, 9(3, p. 378. 
Lee, J., Oh, K-T. \& Kwon, H.Y. (2008) "Striving for transparency and efficiency in e-government: procurement reform through e-procurement”, ACM, Cairo, Egypt, 978-1-60558-386-0.

Lehner, F. \& Haas, N. (2010) "Knowledge management success factors-proposal of an empirical research", Electronic Journal of Knowledge Management, 8(1) 79-90.

Lew, Y.K. \& Sinkovics, R.R. (2012) “Crossing borders and industry sectors: behavioral governance in strategic alliances and product innovation for competitive advantage", Long Range Planning, 46(1-2) 13-38.

Lindskog, H., Brege, S. \& Brehmer, P.O. (2010) "Corruption in public procurement and private sector purchasing”, Organisational Transformation and Social Change, 7(2) 167-88.

Lio, M-C, Liu, M-C \& Ou, Y-P (2011) "Can the internet reduce corruption? A cross-country study based on dynamic panel data models", Government Information Quarterly, 28(1) 47-53.

Magrini, P. (2006) "Transparency in e-procurement: the Italian Perspective", 1st HIGH level seminar on e-procurement $30 \quad-31 \quad$ January $2006 \quad$ Naples, Italy, http://www.oecd.org/dataoecd/57/31/36238443.pdf accessed 10 February 2012

Mahmood, SAI (2010) "Public procurement and corruption in Bangladesh confronting the challenges and opportunities", Journal Of Public Administration And Policy Research, 2(6) 103-11.

Mistry, J.J. \& Jalal, A. (2012) “An empirical analysis of the relationship between e-government and corruption", The International Journal Of Digital Accounting Research, 12(18) 145-76.

Mitchell, K. (2000) "Instituting e-procurement in the public sector", Public Management (PM), 82(11) 21-5.

Ndou, V. (2004) "E-government for developing countries: opportunities and challenges", The Electronic Journal of Information Systems in Developing Countries, 18(1) 1-24.

Nepal, (2010) Nepal Public Procurement Strategic Framework, PPMO Government of Nepal Office of the Prime Minister and Council of Ministers, Kathamndu.

Neupane, A., Soar, J. \& Vaidya, K. (2012a) "Evaluating the anti-corruption capabilities of public eprocurement in a developing country", The Electronic Journal on Information System in Developing Countries, 55(2) 1-17.

Neupane, A., Soar, J. \& Vaidya, K. (2012b) “The potential of E-procurement Technology for Reducing Corruption”, International Journal of Information Technology and Management, 11(4) 273-87.

Neupane, A., Soar, J. \& Vaidya, K. (2014) "Anti-corruption capabilities of public e-procurement technologies: principal-agent theory”, in KJ Bwalya (ed.), Technology Development and Platform Enhancements for Successful Global E-Government Design, Information Science Reference, Hershey, PA. United States) 185-203.

Neupane, A., Vaidya, K. Soar, J. \& Young, J. (2012) "Role of public e-procurement technology to reduce corruption in government procurement", paper presented to 5th International Public Procurement Conference (IPPC5), Seattle, United States, 17-19 August 2012.

OECD (2005) Fighting Corruption and Promoting Integrity in Public Procurement, Organisation for Economic Co-operation and Development,Paris.

OECD (2007) Integrity in public procurement: good practice from A to Z, Organisation for Economic Co-operation and Development, Paris.

OECD (2011) Government at a Glance 2011 Country Note: Finland, OECD, http://www.oecd.org/dataoecd/60/25/47876433.pdf accessed 24 January 2012.

OECD, A. (2008) "Fighting Bribery In Public Procurement In Asia-Pacific". http://www.etransform.org/gti/sites/etransform.org/files/Documents/bribery.pdf accessed 21 July 2011. 
Oh, W., Gallivan, M.J. \& Kim, J.W. (2006) "The market's perception of the transactional risks of information technology outsourcing announcements", Journal of Management Information Systems, 22(4) 271-303.

Oye, N. (2013) "Reducing Corruption in African Developing Countries: The Relevance of E Governance", Greener Journal of Social Sciences, 3(1) 006-13.

Panayiotou, N.A., Gayialis, S.P. \& Tatsiopoulos, I.P. (2004) "An e-procurement system for governmental purchasing”, International Journal of Production Economics, 90(1) 79-102.

Panda, P., Sahu, G. \& Gupta, P. (2010) "Promoting Transparency and Efficiency in Public Procurement: E-Procurement Initiatives by Government of India”, paper presented to 7th International Conference on E-procurement (ICEG) 2010, 20-24 Apr 2010, IIM Banglore, India.

Parigi, V, Leader, W, Geeta, P \& Kailasam, R 2004, Ushering in Transparency for Good Governance, Centre for GoodGovernance, Hyderabad, $30 \quad$ December 2012, $<$ http://www.cgg.gov.in/workingpapers/Ushering_in_Transparency.pdf>.

Pariyar, M.P. (2007) "E-government initiatives in Nepal: challenges and opportunities", paper presented to Proceedings of the 1st International Conference On Theory And Practice Of Electronic Governance, Macao, China, 10-13 December 2007.

Pathak, R., Singh, G., Belwal, R., Naz, R. \& Smith, R. (2008) “'E-governance, corruption and public service delivery: A comparative study of Fiji and Ethiopia", JOAAG, 3(1) 65-79.

Pathak, R.D., Naz, R., Rahman, M.H., Smith, R.F.I. \& Agarwal, K.N. (2009) “'E-governance to cut corruption in public service delivery: a case study of Fiji”, Intl Journal of Public Administration, 32(5) 415-37.

Pellegrini, L. \& Gerlagh, R. (2008) "Causes of corruption: a survey of cross-country analyses and extended results", Economics of Governance, 9(3) 245-63.

Raymond, J. (2008) "Benchmarking in public procurement", Benchmarking: An International Journal, 15(6) 782-93.

Ronchi, S., Brun, A., Golini, R. \& Fan, X. (2010) “What is the value of an IT e-procurement system?”, Journal of Purchasing \& Supply Management, 16(2) 131-40.

Schapper, P. (2008) "The impact of e-procurement on corruption: The potential of e-procurement for curbing corruption risks", paper presented to 7th Regional Seminar On Making International Anti-Corruption Standards Operational, Bali, Indonesia, November 5-7 2007.

Schmidheiny, K. \& Basel, U. (2012) "The bootstrap", Short guides to microeconometrics. Universität Basel., 26, p. 2012.

Shakya, R.K. (2012) "Procurement Governance Framework: Success to E-government Procurement (E-GP) system Implementation", paper presented to 5th International Public Procurement Conference (IPPC5), Seattle, United States, 17-19 August 2012.

Sharma, B. (2012) "Sudan scam: 5 convicted, 31 get clean chit", The Kathmandu Post, 13 February 2012.

Shim, D.C. \& Eom, T.H. (2009) “Anticorruption effects of information communication and technology (ICT) and social capital”, International Review Of Administrative Sciences, 75(1, p. 99.

Singh, G., Pathak, R., Naz, R. \& Belwal, R. (2010) "E-governance for improved public sector service delivery in India, Ethiopia and Fiji”, International Journal of Public Sector Management, 23(3) 254-75.

Singh, J. \& Sirdeshmukh, D. (2000) “Agency and trust mechanisms in consumer satisfaction and loyalty judgments”, Journal of the Academy of Marketing Science, 28(1) 150-67. 
Sohail, M. \& Cavill, S. (2008) “Accountability to prevent corruption in construction projects”, Journal of Construction Engineering and Management, 134(9) 729-38.

Song, H.J. (2002) "Prospects and limitations of the e-government initiative in Korea", International Review of Public Administration, 7(2) 45-53.

Subedi, M.S. (2006) "Corruption In Nepal: An Anthropological Inquiry", Dhaulagiri Journal of Sociology and Anthropology, 1(0) 110-28.

Taylor, P. (2005) "Do public sector contract catering tender procedures result in an auction for "lemons"?", International Journal of Public Sector Management, 18(6) 484-97.

Teo, T.S.H., Lin, S. \& Lai, K-h. (2009) “Adopters and non-adopters of e-procurement in Singapore: An empirical study”, Omega, 37(5) 972-87.

Thai, K.V. (2001) "Public procurement re-examined”, Journal of Public Procurement, 1(1) 9-50.

UN (2006) E-procurement: economic and social commission for Asia and the Pacific Asian Development Bank Institute Public Procurement Service of the Republic of Korea, United Nations publication, Thailand.

UNDP (2006) Capacity Development Practice Note, <http://capacity.undp.org/index.cfm?moduleLibrary\&page=Document\&DovumentID=5599 accessed 15 July 2012.

UNODC (2004) The Global Programme Against Corruption: UN Anti-Corruption Toolkit, 3rd edn, UNODC Vienna.

Vaidya, K. (2007) Electronic Procurement in the Australian Public Sector: The Organizational Assimilation Process and Its Impact on Public Procurement Performance, University of New England.

Vaidya, K. \& Hyde, M. (2011) "Inter-organisational information systems assimilation: an empirical evaluation in light of the diffusion of innovation theory", International Journal of Business Information Systems, 7(3) 247-68.

Vaidya, K., Sajeev, A. \& Callender, G. (2006) "Critical factors that influence e-procurement implementation success in the public sector", Journal of Public Procurement, 6(1/2, p. 70.

Vaidya, K, Callender, G.C. \& Sajeev, A.S.M. (2009) "Facilitators of Public E-Procurement: Lessons Learned from the U.K., U.S., and Australian Initiatives”, in KV Thai (ed.), International Handbook Of Public Procurement, Auerbach Publications Taylor \& Francis Group, 473-90.

Vaidya, K., Callender, G, Sajeev, A \& Gao, J 2004, 'Towards a model for measuring the performance of e-procurement initiatives in the Australian public sector: a balanced scorecard approach', paper presented to A paper prepared for the Australian Electronic Governance Conference. Centre for Public Policy, University of Melbourne, Melbourne Victoria, 14th and 15thApril, 2004.

Vaidyanathan, G. \& Devaraj, S. (2008) "The role of quality in e-procurement performance: An empirical analysis", Journal of Operations Management, 26(3) 407-25.

Van der Heijden, H., Verhagen, T. \& Creemers, M. (2003) "Understanding online purchase intentions: contributions from technology and trust perspectives", European Journal of Information Systems, 12(1) 41-8.

Vinzi, V.E., Trinchera, L \& Amato, S. (2010) "PLS path modeling: from foundations to recent developments and open issues for model assessment and improvement”, Handbook of Partial Least Squares Concepts, Methods and Applications, Springer Berlin Heidelberg.

Ware, G.T., Moss, S., Campos, J.E. \& Noone, G.P. (2012) “'Corruption in Procurement”, in A Graycar \& R Smith (eds), Handbook of Global Research and Practice in Corruption, illustrated edn, Edward Elgar Publishing, UK. 
Waterman, R.W. \& Meier, K.J. (1998) “Principal-agent models: an expansion?”, Journal of Public Administration Research and Theory, 8(2, p. 173.

Wathne, K.H. \& Heide, J.B. (2000) “Opportunism in interfirm relationships: forms, outcomes, and solutions", The Journal of Marketing, 64(4) 36-51.

WB (2004) The cost of corruption, News \& Broadcast, the World Bank ,Washington, DC, USA, http://web.worldbank.org/WBSITE/EXTERNAL/NEWS/0,,contentMDK:20035595 menuPK: 36691 pagePK:116743 piPK:36693 theSitePK:4607,00.html accessed 5 October 2012.

Wen, W. \& Wei, L. (2007) "Decision-making analysis of e-procurement with the rough set theory", paper presented to International Conference on Wireless Communications, Networking and Mobile Computing, Shanghai, 21-25 September 2007.

Wescott, C.G. (2001) "E Government in the Asia pacific region", Asian Journal of Political Science, 9(2) 1-24.

Wetzels, M., Odekerken-Schroder, G. \& Van Oppen, C. (2009) "Using PLS path modeling for assessing hierarchical construct models: Guidelines and empirical illustration”, MISQ, 33(1, p. 177.

Whipple, J.M. \& Roh, J. (2010) "Agency theory and quality fade in buyer-supplier relationships", International Journal of Logistics Management, 21(3) 338-52.

Xinzhang, C. \& Yonggang, W. (2011) "E-government, government procurement and the development of e-Commerce: Korean experience and its implications", paper presented to International Conference on E -Business and E -Government (ICEE), Shanghai, China, 6-8 May 2011.

Yusoff, W.S. \& Islam, M. (2011) "Electronic Government Procurement Adoption Behavior amongst Malaysian SMEs”, International Business Research, 4(1) 100.

Zhang, H. \& Yang, J. (2011) "'Research on Application of E-Tender in China", paper presented to Internet Technology and Applications (iTAP), 2011 International Conference on, 16-18 Aug. 2011.

Zhang, J. \& Zhang, Z. (2009) “Applying E-Government Information System for Anti-corruption Strategy", paper presented to Management of e-Commerce and e-Government, 16-19 September, Nanchang, China.

\section{APPENDIX A}

Questionnaire: A five point Likert scales was used to measure the perception of the government officers about the evaluation of public e-procurement technology to reduce corruption in public procurement.

\section{Reducing monopoly power through e-procurement technology}

MP1 E-procurement technology provides our department auditing capabilities with real time procurement information.

MP2 E-procurement technology reduces monopolies or selection of favoured bidders (e.g. suppliers / vendors) in contracting process.

MP3: The potential of e-procurement technology improves internal efficiency across procurement process (e.g. tender notice time, reduce paper files, advertisement time), which reduces the monopoly power of government officers in tendering process.

MP4: E-procurement technology facilitate accounting control it reduces the likelihood of fraud or accounting errors by enabling the electronic matching of requisition, purchase orders, invoice, and receipts. 
MP5: E-procurement technology helps to provide fix price contract to all buyers and sellers (e.g. equal tendering price for all bidders, price shall fixed throughout the contract).

\section{Reducing Information Asymmetry through e-procurement technology}

IA1: E-procurement technology helps to more competition in terms of quantity (participation) and quality (openness and fairness) among our bidders in tendering process.

IA2: Our department has frequently up-to-date procurement information (e.g. tender notice) posted in our procurement web portal.

IA3: E-procurement helps to track and monitor all the procurement related activities such as tracking bidders' information, monitoring all procurement processes etc.

IA4: E-procurement technology provides consistency in procurement process (same rule and regulation to all bidders in tendering process) to all registered bidders.

IA5: E-procurement technology reduces discretion (e.g. limit financial delegation) in contracting process.

\section{Increasing transparency and accountability through e-procurement technology}

TA1: E-procurement technology contributes us to enhance more transparent and accountable in procurement process.

TA2: E-procurement technology helps to reduce human errors (e.g. tender checklists) as well as increase accuracy of orders in procurement process.

TA3: E-procurement makes it more convenient to acquire information.

TA4: All government procurement policies, processes, and guidelines are available online (eprocurement portal).

TA5: E-procurement provides the better relationship between government and suppliers.

TA6: E-procurement brings an increase in transmission of timely public information on contract awards on price, volume, and execution of time.

TA7: E-procurement increases the availability of public information on bids/offers and other processes.

TA8: E-procurement can increase accuracy of orders.

\section{Intent to adopt anti-corruption technology (e-procurement)}

ITA1: Our organization would like to intent-to-adopt e-procurement system for our organization needs.

ITA2: Our organization is using e-procurement technology for handling our procurement-processing task (e.g. tendering, contract awards etc.)

ITA3: E-procurement helps our organization to coordinate with other bidders partners for government work and services.

ITA4: Our organization adopts e-procurement system to enhance procurement efficiency and for better decision making in government work and services.

ITA5: Our organizations adopt e-procurement system to avoid the human interference in public tendering process.

ITA6: Overall, our organization intent to adopt e-procurement system to increase transparency, for non-discrimination, equality of access, and open competition in government work and services. 
APPENDIX B

\section{Cross loading table}

\begin{tabular}{|c|c|c|c|c|}
\hline Variables & $\begin{array}{l}\text { Monopoly of } \\
\text { power (MP) }\end{array}$ & $\begin{array}{l}\text { Information } \\
\text { Asymmetry (IA) }\end{array}$ & $\begin{array}{l}\text { Transparency } \\
\text { and } \\
\text { accountability } \\
\text { (TA) }\end{array}$ & $\begin{array}{l}\text { Intent to adopt } \\
\text { e-procurement } \\
\text { (ITA) }\end{array}$ \\
\hline MP1 & 0.773 & & & \\
\hline MP2 & 0.869 & & & \\
\hline MP3 & 0.597 & & & \\
\hline MP4 & 0.944 & & & \\
\hline MP5 & 0.764 & & & \\
\hline IA1 & & 0.578 & & \\
\hline IA2 & & 0.924 & & \\
\hline IA3 & & 0.481 & & \\
\hline IA4 & & 0.821 & & \\
\hline IA5 & & 0.543 & & \\
\hline TA1 & & & 0.718 & \\
\hline TA2 & & & 0.849 & \\
\hline TA3 & & & 0.847 & \\
\hline TA4 & & & 0.527 & \\
\hline TA5 & & & 0.789 & \\
\hline TA6 & & & 0.859 & \\
\hline TA7 & & & 0.605 & \\
\hline TA8 & & & 0.634 & \\
\hline ITA1 & & & & 0.486 \\
\hline ITA2 & & & & 0.703 \\
\hline ITA3 & & & & 0.891 \\
\hline ITA4 & & & & 0.813 \\
\hline ITA5 & & & & 0.823 \\
\hline ITA6 & & & & 0.697 \\
\hline
\end{tabular}

